\title{
Alteration of gene expression in response to bone morphogenetic protein- 2 in androgen-dependent human prostate cancer LNCaP cells
}

\author{
TORU KUMAGAI, KENTARO TOMARI, TAKAHISA SHIMIZU and KEN TAKEDA \\ Department of Hygiene-Chemistry, Faculty of Pharmaceutical Sciences, \\ Tokyo University of Science, 2641 Yamazaki Noda-shi, Chiba 278-8510, Japan
}

Received August 26, 2005; Accepted October 14, 2005

\begin{abstract}
Bone morphogenetic protein (BMP)-2, a multifunctional member of the transforming growth factor (TGF)- $\beta$ superfamily with powerful osteoinductive effects, has various biological activities in a variety of cells. We observed that BMP-2 inhibits cell proliferation in the androgen-dependent human prostate cancer cell line, LNCaP. To investigate the mechanism of inhibition of androgen-dependent growth by BMP-2, we compared the gene expression in LNCaP cells treated with dihydrotestosterone (DHT) to that of LNCaP cells treated with DHT and BMP-2, using DNA microarray analysis. Of 8,400 human genes on the gene chip, 38 genes were up-regulated by $>2.0$-fold and 48 genes were downregulated by $<0.5$-fold by treatment with BMP-2. These genes were involved in a variety of cellular functions, including signal transduction, transcription regulation, enzymes, transporters, structural molecules and translation. RT-PCR analysis showed that $\mathrm{CH} 1 \mathrm{CL}$ and BMX were up-regulated and DACH1 and WNT5A were down-regulated by treatment with BMP-2. Furthermore, we detected an increase of WNT5A protein in the medium by DHT and inhibition of the increase by BMP-2. In the present study, we identified several BMP-2responsive genes in LNCaP cells. Further studies of the roles of these genes may clarify the mechanisms underlying the inhibition of cell proliferation by BMP-2 and identify better approaches for the prevention and treatment of prostate cancer.
\end{abstract}

\section{Introduction}

Bone morphogenetic proteins (BMPs) are secreted signaling molecules that belong to the transforming growth factor (TGF)- $\beta$ superfamily $(1,2)$ and were originally identified from extracts of bone on the basis of their ability to induce

Correspondence to: Dr Ken Takeda, Department of HygieneChemistry, Faculty of Pharmaceutical Sciences, Tokyo University of Science, 2641 Yamazaki Noda-shi, Chiba 278-8510, Japan

E-mail: takedak@rs.noda.tus.ac.jp

Key words: prostate cancer, LNCaP, androgen, BMP-2, DNA microarray ectopic bone formation in vivo $(3,4)$. In addition to functions as a possible bone-inducing factor, BMPs have been shown to play important roles in various biological processes such as chemotaxis of monocytes (5), migration of osteoblasts (6) and differentiation of neural cells (7). BMPs and their receptors are widely distributed not only in bone and cartilage but also in other tissue. BMP receptor (BMPR) mRNA is expressed at higher levels in the prostate than in other organs (8), and the expression of BMPRs (9) and BMP-2 (10) decreases with the progression of prostate cancer. We were interested in the relationship between BMP-2 and prostate cancer and, therefore, investigated the effect of BMP-2 on prostate cancer cell lines. BMP-2 inhibited the androgendependent growth of human prostate cancer LNCaP cells; however, it had no effect on the growth of androgenindependent prostate cancer cell lines. Ide et al (11) reported a similar result. Recently, we suggested that the alteration of some cell cycle-related proteins is associated with growth inhibition (12). However, the mechanism underlying the inhibitory effect of BMP-2 on prostate cancer cell proliferation is not fully understood.

In the present study, to investigate the mechanism underlying the inhibitory effect of BMP-2 on the growth of androgen-dependent prostate cancer cells, we examined the pattern of global gene expression in LNCaP cells treated with dihydrotestosterone (DHT) alone or with a combination of DHT and BMP-2 using microarray analysis. DNA microarrays are useful for the study of the regulation of gene expression in cancer cells, particularly in examining the changes in gene expression associated with the development and progression of many cancers, including prostate cancer. We compared the gene expression in LNCaP cells treated with DHT to that of LNCaP cells treated with DHT and BMP-2 and identified various novel putative BMP-2-responsive genes involved in several cellular functions, including signal transduction, transcription regulation, transport, structure, and translation regulation.

\section{Materials and methods}

Cell culture and treatment. The human prostate cancer cell line, LNCaP [American Type Culture Collection (ATCC), VA, USA], was maintained in RPMI-1640 medium (Gibco, NY, USA) supplemented with $10 \%$ fetal bovine serum (FBS) 
(ATCC) at $37^{\circ} \mathrm{C}$ in a humidified $5 \% \mathrm{CO}_{2}$ incubator. To measure the effect of recombinant human BMP-2 (rhBMP-2) on the androgen-induced proliferation of $\mathrm{LNCaP}$ cells, $5.0 \times 10^{6}$ cells were seeded in a 100-mm dish in phenol red-free RPMI-1640 containing 5\% charcoal-dextran-treated FBS. After 1 day of growth in androgen-depleted medium, cells were treated with dihydrotestosterone (DHT; Sigma-Aldrich, MO, USA) at a final concentration of $1 \mathrm{nM}$ and rhBMP-2 at a final concentration of $100 \mathrm{ng} / \mathrm{ml}$. rhBMP-2 was provided by Yamanouchi Pharmaceutical Co., Ltd. (Japan).

Crystal violet assay. LNCaP cells were seeded into 24-well plates $\left(2 \times 10^{4}\right.$ cells/well $)$. LNCaP cells were cultured as described above. After cells were treated with $1 \mathrm{nM}$ DHT alone or with a combination of $1 \mathrm{nM}$ DHT and $100 \mathrm{ng} / \mathrm{ml}$ BMP-2 for 1, 2 or 4 days, formaldehyde was added to a final concentration of $2 \%$ for fixation, the medium was removed from the wells and the plate was washed with $0.9 \% \mathrm{NaCl}$. Crystal violet solution was added, and cells were incubated for $30 \mathrm{~min}$ at room temperature. Cells were then washed with $0.9 \% \mathrm{NaCl}$ followed by addition of $1 \%$ SDS to solubilize the cells. The solution was transferred to 96-well plates, and the absorbance of each well at $595 \mathrm{~nm}$ was determined.

RNA extraction. LNCaP cells grown to $70 \%$ confluence were treated with $1 \mathrm{nM}$ DHT in the absence or presence of $100 \mathrm{ng} / \mathrm{ml}$ BMP-2 for $24 \mathrm{~h}$. Total RNA from LNCaP cells was extracted using isogen (Wako, Japan). RNA concentrations were measured at $260 \mathrm{~nm}$. For DNA microarray assay, poly(A)+ RNA was extracted using an Oligotex TM-dT30 Super mRNA purification kit (Takara, Japan). Poly(A) ${ }^{+}$RNA quality was assessed using an Agilent BioAnalyzer (Agilent Technologies, CA, USA) and poly(A) ${ }^{+}$RNA quantity was assessed using ND-1000 (NanoDrop Technologies, DE, USA). For reverse transcription polymerase chain reaction (RT-PCR), poly(A)+ RNA was extracted using an Oligotex-dT30 (Takara).

DNA microarray and data analysis. mRNAs were labeled with different fluorescent labels for application on gene chips. For assessing the quality of biotin-labeled RNA, actin and GAPDH were examined using a test chip and GeneChip Operating Software (GCOS; Affymetrix Inc., CA, USA). For additional information, see www.biomatrix.co.jp. Samples were processed on the chips. The human genome focus GeneChip array (Affymetrix, Inc.) was used to study changes in expression of 8,400 human genes. GCOS was used for initial data analysis. GeneSpring 5.0 (Silicon Genetics, CA, USA) software was used to compare changes in gene expression between treatments. More than 2.0-fold and $<0.5$-fold changes in gene expression were the cut-offs used for determination of significant changes in expression.

$R T$-PCR. A subset of high- and low-expressed genes was confirmed by RT-PCR with sequence-specific primers. Reverse transcription of mRNA into cDNA was performed using a Bulk First-Strand cDNA reaction mix (Amersham Biosciences, NJ, USA). Briefly, $1 \mu \mathrm{g}$ of mRNA was reverse transcribed with $\operatorname{pd}(\mathrm{N}) 6$ primer in a final volume of $30 \mu 1$, and the resulting cDNA was amplified by PCR. The program used requires suitable cycles with the following conditions: $95^{\circ} \mathrm{C}$ for $30 \mathrm{sec}$

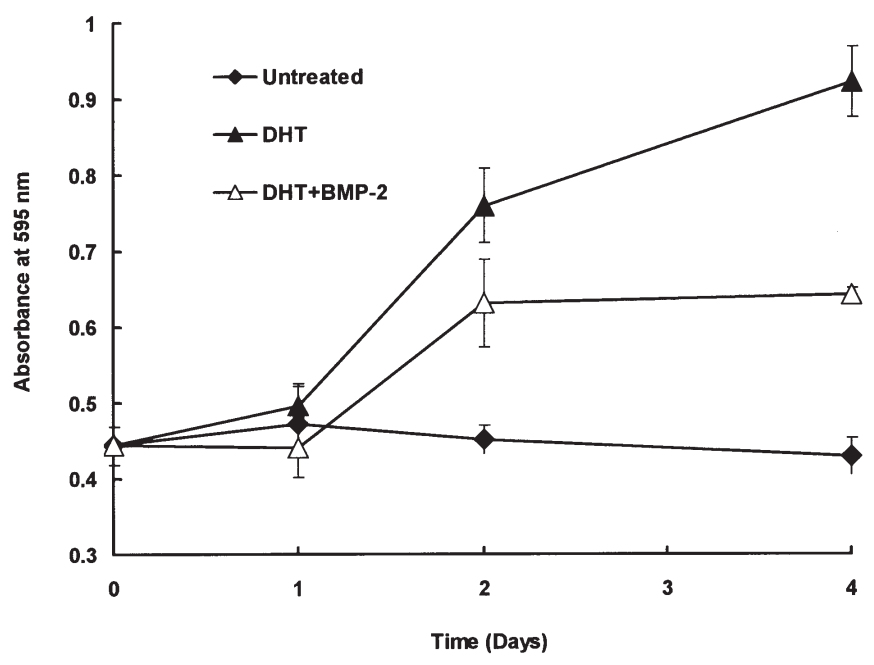

Figure 1. Effect of BMP-2 on androgen-dependent growth of LNCaP cells. Cells were seeded into 24 -well plates $\left(2 \times 10^{4}\right.$ cells/well) and cultured in phenol red-free RPMI-1640 containing 5\% charcoal-dextran-treated FBS for $24 \mathrm{~h}$. Cells were then treated with $1 \mathrm{nM}$ DHT alone or with a combination of $1 \mathrm{nM} \mathrm{DHT}$ and $100 \mathrm{ng} / \mathrm{ml} \mathrm{BMP-2.} \mathrm{After} \mathrm{treatment} \mathrm{for} \mathrm{1,} 2$ or 4 days, cell growth was analyzed as described in Materials and methods. The absorbance at $595 \mathrm{~nm}$ is correlated with the number of living cells.

(10 min for the first cycle); $55^{\circ} \mathrm{C}$ for $1 \mathrm{~min}$; and $72^{\circ} \mathrm{C}$ for $2 \mathrm{~min}$ (10 min for the last cycle). PCR products were separated by $2 \%$ agarose gel electrophoresis. PCR primers were as follows: BMX sense, 5'-GTTGCCAGCAGAGCTGTAAA-3' and antisense, 5'-GGAGATGTTACCAGCAAACCA-3'; CH1CL sense, 5'-AGATGACTGAATACTGGGTTCCAGA-3' and antisense, 5'-GGCAGTCCCTTTGTCAACTTTTC-3'; DACH1 sense, 5'-TGCTGCTACCAATGCAGCTAT-3' and antisense, 5'-TGTTCACGCCGTTTCGTCT-3'; GAPDH sense, 5'-ATC ATCAGCAATGCCTCCTG-3' and antisense, 5'-CTGCTTC ACCACCTTCTTGA-3'; JAK-2 sense, 5'-ACCTCTAAGTG CTCTGGATT-3' and antisense, 5'-TCTCTTAGGTGCTC TTCAGT-3'; RARA sense, 5'-CAACAGCTCAGAACAAC GTG-3' and antisense, 5'-GATCTCCATCTTCAGCGTGA-3'; TGFBR2 sense, 5'-TGTGTGACTTTGGGCTTTCC-3' and antisense, 5'-TGTTTAGGGAGCCGTCTTCA-3'; and WNT5A sense, 5'-CCGATTTAGCAGTGTCAGCGT-3' and antisense, 5'-CCTGTGCCTTCGTGCCTATTT-3'.

Western blot analysis. LNCaP cells grown to $70 \%$ confluence were treated with $1 \mathrm{nM}$ DHT in the absence or presence of $100 \mathrm{ng} / \mathrm{ml} \mathrm{BMP}-2$ for $24 \mathrm{~h}$. After treatment, cell cultures were washed twice with phosphate-buffered saline (PBS) and incubated for $24 \mathrm{~h}$ at $37^{\circ} \mathrm{C}$ in fresh phenol red-free RPMI1640 (serum-free). Conditioned medium was then harvested, centrifuged to remove cells, and concentrated using MicroconYM10 tubes (Millipore, Bedford, MA, USA). Cell numberstandardized conditioned medium was analyzed by SDSpolyacrylamide gel electrophoresis (SDS-PAGE). The proteins were transferred to a polyvinylidene difluoride membrane. The blots were blocked at $4{ }^{\circ} \mathrm{C}$ with $5 \%$ non-fat milk overnight in PBS-T (10 mM PBS and 0.05\% Tween-20) and incubated for $2 \mathrm{~h}$ at room temperature with a polyclonal anti-Wnt5a antibody (Santa Cruz Biotechnology, CA, USA). The blots were then washed three times and incubated for $1 \mathrm{~h}$ with HRP- 
Table I. Genes up-regulated in LNCaP cells after treatment with DHT and BMP-2 rather than DHT alone.

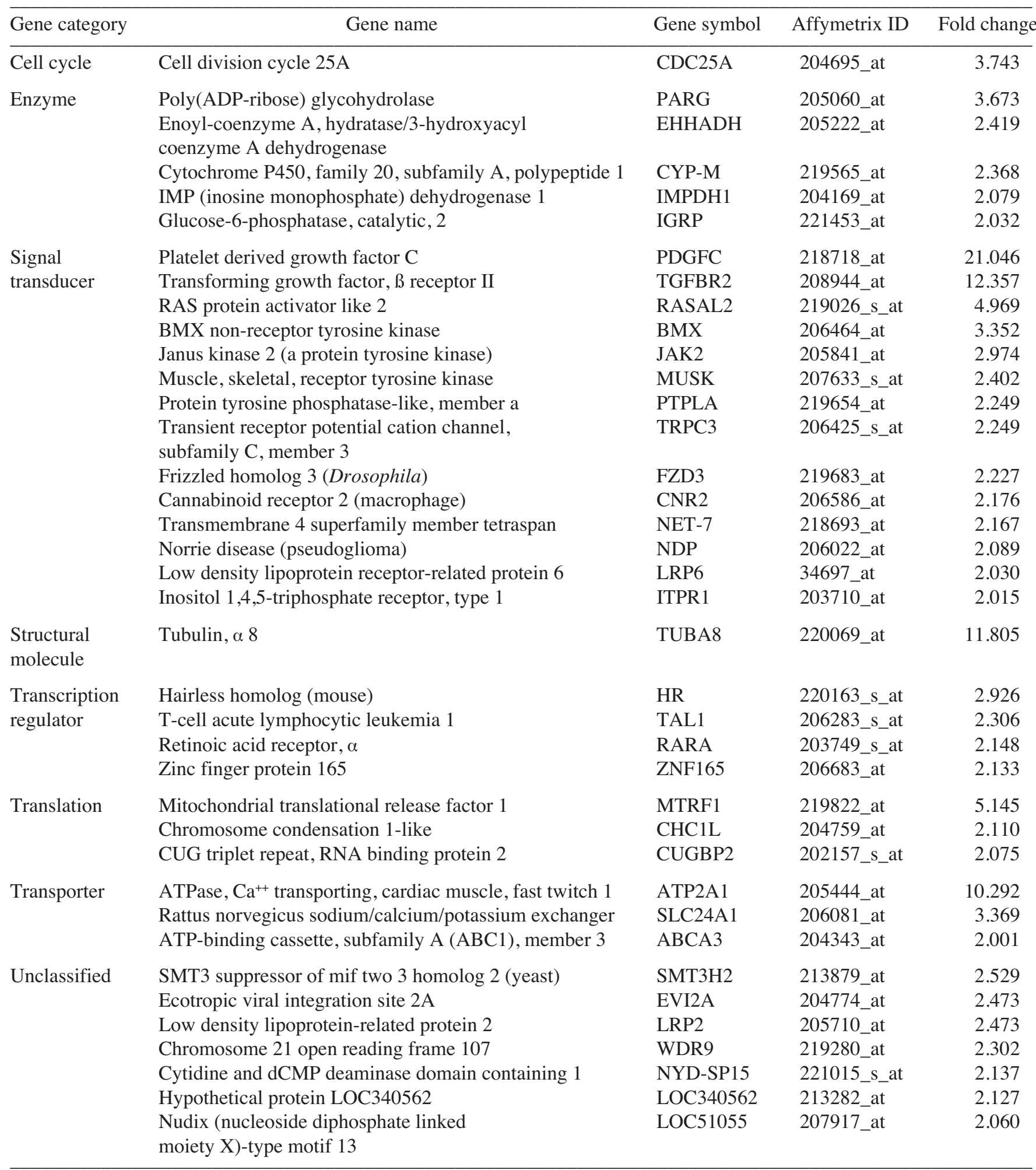

conjugated secondary antibodies. Immunoreactive proteins were visualized using an enhanced chemiluminescence detection system (Amersham Biosciences).

\section{Results}

DHT-induced growth of LNCaP cells was inhibited by BMP-2. To analyze the effect of BMP-2 on DHT-induced proliferation of LNCaP cells, cells grown for $24 \mathrm{~h}$ in androgen-depleted medium were treated with $1 \mathrm{nM}$ DHT alone and with $1 \mathrm{nM}$ DHT plus $100 \mathrm{ng} / \mathrm{ml}$ BMP-2. After treatment for 1, 2 and 4 days, cell growth was analyzed by crystal violet assay (Fig. 1). The number of cells treated with $1 \mathrm{nM}$ DHT was approximately 2.1 -fold greater on day 4 than the number of untreated control cells. However, treatment with a combination of DHT and BMP-2 yielded only a 1.5-fold increase. In other words, 
Table II. Genes down-regulated in LNCaP cells after treatment with DHT and BMP-2 rather than DHT alone.

\begin{tabular}{|c|c|c|c|c|}
\hline Gene category & Gene name & Gene symbol & Affymetrix ID & Fold change \\
\hline $\begin{array}{l}\text { Apoptosis } \\
\text { regulator }\end{array}$ & Baculoviral IAP repeat-containing 7 (livin) & BIRC7 & 220451_s_at & 0.475 \\
\hline \multirow{2}{*}{$\begin{array}{l}\text { Cell adhesion } \\
\text { molecule }\end{array}$} & Vinexin $\beta$ (SH3-containing adaptor molecule-1) & SCAM-1 & 209253_at & 0.342 \\
\hline & Vasodilator-stimulated phosphoprotein & VASP & 202205_at & 0.457 \\
\hline \multirow[t]{5}{*}{ Enzyme } & Glucosaminyl (N-acetyl) transferase 3 , mucin type & GCNT3 & 219508_at & 0.203 \\
\hline & Transmembrane protease, serine 3 & TMPRSS3 & 220177_s_at & 0.281 \\
\hline & A disintegrin and metalloproteinase domain 18 & ADAM18 & 207597_at & 0.360 \\
\hline & Cytochrome b-561 & CYB561 & 210816_s_at & 0.447 \\
\hline & Sialyltransferase 7D & SIAT7D & 220937_s_at & 0.478 \\
\hline $\begin{array}{l}\text { Enzyme } \\
\text { regulator }\end{array}$ & $\begin{array}{l}\text { Serine (or cysteine) proteinase inhibitor, } \\
\text { clade B (ovalbumin), member } 13\end{array}$ & SERPINB13 & 211362_s_at & 0.212 \\
\hline Motor & Kinesin family member $5 \mathrm{~A}$ & KIF5A & 205318_at & 0.400 \\
\hline \multirow{16}{*}{$\begin{array}{l}\text { Signal } \\
\text { transducer }\end{array}$} & Toll-like receptor 7 & TLR7 & 220146_at & 0.110 \\
\hline & Toll-like receptor 3 & TLR3 & 206271_at & 0.204 \\
\hline & Leukemia inhibitory factor receptor & LIFR & 205876_at & 0.235 \\
\hline & Inositol polyphosphate-4-phosphatase, type II, $105 \mathrm{kDa}$ & INPP4B & 205376_at & 0.246 \\
\hline & Tachykinin receptor 1 & TACR1 & 208048_at & 0.276 \\
\hline & IL2-inducible T-cell kinase & ITK & 211339_s_at & 0.328 \\
\hline & Endothelin receptor type B & EDNRB & 204271_s_at & 0.340 \\
\hline & Taste receptor, type 2 , member 16 & TAS2R16 & 221444_at & 0.363 \\
\hline & Rho GDP dissociation inhibitor (GDI) $\alpha$ & ARHGDIA & 213606_s_at & 0.372 \\
\hline & vav 2 oncogene & VAV2 & 205536_at & 0.397 \\
\hline & Protein kinase, cGMP-dependent, type II & PRKG2 & 207505_at & 0.411 \\
\hline & Mitogen-activated protein kinase 8 interacting protein 1 & MAPK8IP1 & 213014_at & 0.444 \\
\hline & InaD-like protein & INADL & 214705_at & 0.453 \\
\hline & Calcitonin receptor-like & CALCRL & 206331_at & 0.455 \\
\hline & Mitogen-activated protein kinase kinase kinase 8 & MAP3K8 & 205027_s_at & 0.462 \\
\hline & Wingless-type MMTV integration site family, member 5A & WNT5A & 205990_s_at & 0.491 \\
\hline \multirow{4}{*}{$\begin{array}{l}\text { Structural } \\
\text { molecule }\end{array}$} & Amelogenin (amelogenesis imperfecta 1, X-linked) & AMELX & 208410_x_at & 0.112 \\
\hline & Peanut-like 1 (Drosophila) & PNUTL1 & 209767_s_at & 0.322 \\
\hline & Myosin, heavy polypeptide 13 , skeletal muscle & MYH13 & 208208_at & 0.326 \\
\hline & Myosin binding protein $\mathrm{C}$, slow type & MYBPC1 & 214087_s_at & 0.367 \\
\hline \multirow{8}{*}{$\begin{array}{l}\text { Transcription } \\
\text { regulator }\end{array}$} & Histone $1, \mathrm{H} 4 \mathrm{f}$ & H4FC & 208026_at & 0.031 \\
\hline & Chromodomain helicase DNA binding protein 2 & CHD2 & 203461_at & 0.280 \\
\hline & ets variant gene 7 (TEL2 oncogene) & ETV7 & 221680_s_at & 0.290 \\
\hline & Histone $1, \mathrm{H} 4 \mathrm{~g}$ & H4FL & 208551_at & 0.400 \\
\hline & Homeo box B6 (HOXB6) & HOXB6 & 205366_s_at & 0.442 \\
\hline & $\begin{array}{l}\text { SWI/SNF related, matrix associated, actin } \\
\text { dependent regulator of chromatin }\end{array}$ & SMARCA1 & 203874_s_at & 0.446 \\
\hline & TEA domain family member 1 & TEAD1 & 214600_at & 0.481 \\
\hline & Dachshund homolog 1 (Drosophila) & $\mathrm{DACH}$ & 205471_s_at & 0.487 \\
\hline \multirow[t]{2}{*}{ Translation } & Ribosomal protein S20 & RPS20 & 216247_at & 0.045 \\
\hline & Polypyrimidine tract binding protein 1 & PTBP1 & 212016_s_at & 0.469 \\
\hline \multirow[t]{4}{*}{ Transporter } & $\begin{array}{l}\text { Solute carrier organic anion transporter } \\
\text { family, member } 1 \mathrm{~B} 1\end{array}$ & SLCO1B1 & 210366_at & 0.063 \\
\hline & Solute carrier family 7, member 1 & SLC7A1 & 206566_at & 0.449 \\
\hline & Sodium channel, voltage-gated, type I, $\beta$ & SCN1B & 205508_at & 0.489 \\
\hline & Adaptor-related protein complex 4 , mu 1 subunit & AP4M1 & 209837_at & 0.500 \\
\hline \multirow[t]{4}{*}{ Unclassified } & Spermatogenesis associated 1 & SPATA1 & 221057_at & 0.303 \\
\hline & Chromosome 13 open reading frame 24 & PIBF1 & 213239_at & 0.348 \\
\hline & Transgelin & TAGLN & 205547_s_at & 0.357 \\
\hline & Chromosome 8 open reading frame 1 & C8orf1 & 41553_at & 0.493 \\
\hline
\end{tabular}




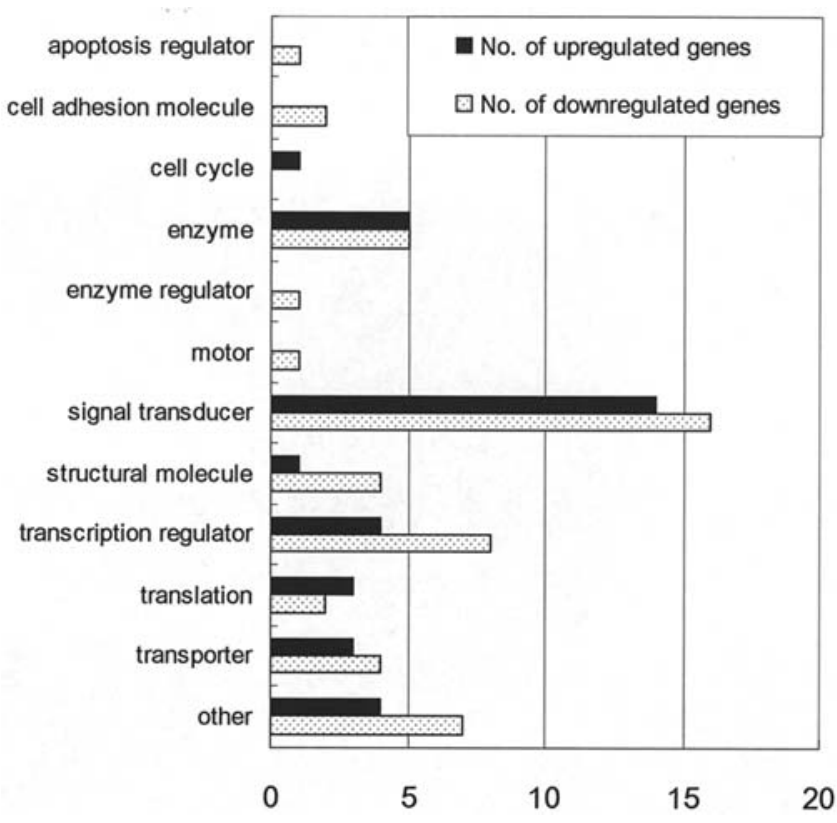

Figure 2. Categories of genes showing differential expression in response to BMP-2. Genes expressed in LNCaP cells treated with DHT alone or with a combination of DHT and BMP-2 were assigned to categories according to biological functions per the Gene Ontology database. The numbers of upand down-regulated genes are shown for each gene category.

treatment with BMP-2 resulted in a $57 \%$ reduction of DHTinduced proliferation of LNCaP cells on day 4 .

Analysis of gene expression by DNA microarray analysis. To investigate the mechanism underlying the action of BMP-2 on androgen-dependent prostate cancer LNCaP cells, RNA samples were prepared from cells treated with $1 \mathrm{nM}$ DHT alone and with $1 \mathrm{nM}$ DHT plus $100 \mathrm{ng} / \mathrm{ml} \mathrm{BMP-2}$ for $24 \mathrm{~h}$ and analyzed on the Affymetrix Human Genome Focus GeneChip Array. To fully understand the biological significance of the global changes in gene expression, microarray expression data were analyzed by GeneSpring 5.0 software and categorized by the Gene Ontology database. Genes up-regulated and downregulated by co-treatment with BMP-2 and DHT compared with treatment with DHT alone are listed in Tables I and II. Thirty-eight genes were up-regulated by $>2.0$-fold, and 48 genes were down-regulated by $<0.5$-fold. There were relatively few up-regulated genes, approximately $79 \%$ of the number of down-regulated genes.

These 86 differentially expressed genes were assigned to various functional gene categories by the GeneOntology database. Thirty $(34.9 \%)$ genes were classified as signal transducers, $12(14.0 \%)$ were transcription regulators, 10 $(11.6 \%)$ were enzymes, $7(8.1 \%)$ were transporters and 5 $(5.8 \%)$ were structural molecules and translations (Fig. 2). The inhibitory effect of BMP-2 on the androgen-dependent growth of LNCaP cells may be associated with modulation of a variety of signal transducers and transcription regulators. Signaling molecules in a variety of pathways were modulated in LNCaP cells treated with BMP-2 for $24 \mathrm{~h}$. These signaling molecules include components of the mitogen-activated protein kinase (MAPK) pathway, such as MAPK8IP1 and MAP3K8; the inositol phosphorylation pathway, such as
A

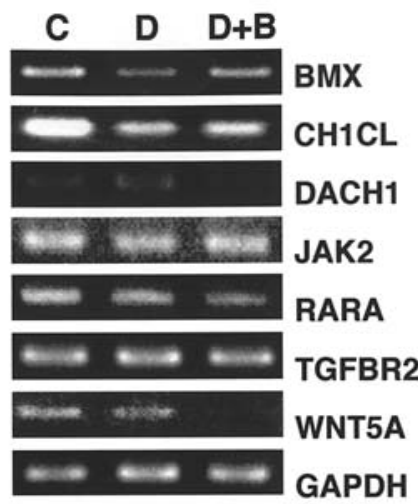

B

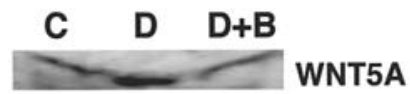

Figure 3. (A) Expression levels of various mRNAs in LNCaP cells treated with DHT alone and with a combination of DHT and BMP-2. mRNAs from untreated (control) LNCaP cells, cells treated with DHT alone and cells treated with both DHT and BMP-2 for $24 \mathrm{~h}$ were extracted and used as templates for the synthesis of cDNAs. After normalization of cDNA concentrations, RT-PCR analysis was performed as described in Materials and methods. The data shown are control (C), DHT (D), and DHT plus BMP-2 (D+B). (B) Effect of DHT and BMP-2 on the secretion of WNT5A protein in LNCaP cells. Cells were treated with DHT alone and a combination of DHT and BMP-2 for $24 \mathrm{~h}$. After treatment, cells were incubated in fresh phenol red-free RPMI-1640 (serum-free) for $48 \mathrm{~h}$. Conditioned medium was concentrated with Microcon-YM10 tubes and subjected to Western blot analysis. Western blot analysis was performed as described in Materials and methods. The data shown are control (C), DHT (D), and DHT plus BMP-2 (D+B).

INPP4B and ITPR1; and the Ras-related pathway, such as CHC1L, GDI and RASAL2. Furthermore, the expression of other signaling proteins involved in cell proliferation and differentiation, such as WNT5A, DACH1, BMX and JAK2, was altered. Interestingly, receptors regulating cell proliferation, including TGFBR2 and RARA, were up-regulated by co-treatment with BMP-2. In addition, BMP-2 regulated the expression of molecules related to chromatin remodeling, such as CHD2 and SMARCA1.

Confirmation of DNA microarray data. To confirm the gene expression changes observed in the microarray analysis, several genes related to proliferation or malignant changes were selected and analyzed by RT-PCR. RT-PCR analysis was performed using mRNA samples isolated from untreated (control) LNCaP cells, LNCaP cells treated with $1 \mathrm{nM}$ DHT alone, and LNCaP cells treated with $1 \mathrm{nM} \mathrm{DHT}$ and $100 \mathrm{ng} / \mathrm{ml}$ BMP-2 for $24 \mathrm{~h}$ in phenol red-free RPMI-1640 with 5\% charcoal-dextran-stripped FBS. The results are shown in Fig. 3A. RT-PCR analyses revealed patterns of expression similar to those of the microarray analysis for several genes. Increased expression of $\mathrm{CH} 1 \mathrm{CL}$ and BMX genes by BMP-2 was confirmed by RT-PCR. A decrease in the expression of DACH1 and WNT5A by BMP-2 was also confirmed. However, the increase in expression of RARA, JAK2 and TGFBR2 was not confirmed. Next, we examined the alteration 
of the WNT5A protein level in medium after treatment with DHT alone and DHT plus BMP-2 using Western blot analysis (Fig. 3B). Secretion of WNT5A was increased by treatment with DHT alone, and the increase was inhibited by co-treatment with BMP-2.

\section{Discussion}

In the present study, we showed that BMP-2 induced growth arrest of $\mathrm{LNCaP}$ cells is accompanied by a substantial change in gene expression. BMP-2 was first identified as a factor that induces bone and cartilage formation, and the BMP pathway was subsequently shown to be involved in cellular differentiation, organogenesis, chemotaxis and cellular proliferation $(13,14)$. While several gene expression studies have been performed on BMP-2-treated mesenchymalderived cells, little is known about the gene expression profile in BMP-2-treated neoplasias. Comparison of our results with those of other microarray studies of the effects of BMP-2 on mesenchymal precursor cells did not reveal much overlap in the putative target genes (15-18). This suggests that the effect of BMP-2 in different cells may involve different molecular mechanisms and that the regulation of gene expression by BMP-2 is cell-specific.

To define how BMP-2 inhibits the DHT-induced proliferation of $\mathrm{LNCaP}$ cells and thus affects various cellular functions, differentially expressed genes were assigned to categories according to their biological functions per the Gene Ontology database. This categorization of data revealed that genes involved in signal transduction and transcription regulation showed the greatest changes in expression, suggesting that several types of genes are involved in the growth inhibition by BMP-2. RT-PCR analysis confirmed that expression of $\mathrm{CH} 1 \mathrm{CL}$ and BMX was up-regulated and that expression of DACH1 and WNT5A was down-regulated.

The CHC1L gene encodes a member of the RCC1-related guanine nucleotide exchange factor (GEF) family. The Nterminal half of the amino-acid sequence is similar to the regulator of chromosome condensation $\mathrm{RCC} 1$, which acts as a GEF protein for the Ras-related GTPase Ran $(19,20)$. Loss of heterozygosity of chromosome 13q14.2-q14.3 is one of the most frequent aberrations observed in prostate tumors (21-25). CHC1L is located in the last region and differs significantly in expression between normal and neoplastic prostate tissue (26). CHC1L may be important in the control of nuclear-cytoplasmic transport and cell cycle progression through a Ras-related signal transduction pathway. BMX is a member of the Btk tyrosine kinase family and is preferentially expressed in epithelial and endothelial cells including prostate cancer cells (27). IL-6 induced both suppression of growth and neuroendocrine-like differentiation and BMX is required for this process (28). Although the role of pathways via CHC1L or BMX have yet to be identified in the prostate, the change in expression of these genes may be involved in the BMP-2mediated growth inhibition of LNCaP cells.

DACH1 is a member of the Ski gene family. Ski oncoprotein dramatically affects cell growth, differentiation, and/or survival through interaction with various cofactor transcription factors including Smads. Some groups have reported that Ski represses BMP signaling by interacting with and repressing the activity of Smad complexes $(29,30)$. Wu et al showed that DACH1 participates in the negative regulation of TGF- $\beta$ signaling by interacting with NCoR and Smad4 (31). The decrease in expression of the DACH1 gene may lead to the enhancement of BMP-2 signaling in LNCaP cells. WNT5A is a member of the WNT gene family, which consists of structurally related genes that encode secreted signaling molecules. Several studies suggest that WNT5A has growthenhancing or oncogenic properties (32-35). Furthermore, upregulation of the WNT5A mRNA level has been observed in human primary prostate cancer (36). These results indicate the possibility that down-regulation of the expression of DACH1 and WNT5A plays an important role in the process of BMP-2 induced growth inhibition of LNCaP cells.

In conclusion, our results indicate that BMP-2 increases the expression of $\mathrm{CHC} 1 \mathrm{~L}$ and BMX genes and decreases the expression of WNT5A and DACH1 genes, raising the possibility that these genes are involved in the BMP-2mediated inhibition of LNCaP cell proliferation. Our analyses also revealed several novel putative BMP-2 responsive genes involved in a variety of cellular functions and provide support for a role of BMP-2 in the inhibition of cell proliferation. Further studies are needed to clarify the roles of these genes in the inhibition of prostate cancer cell proliferation by BMP-2.

\section{References}

1. Wozney JM, Rosen V, Celeste AJ, Mitsock LM, Whitters MJ, Kriz RW, Hewick RM and Wang EA: Novel regulators of bone formation: molecular clones and activities. Science 242: $1528-1534,1988$

2. Wozney JM: Bone morphogenetic proteins. Prog Growth Factor Res 1: 267-280, 1989.

3. Urist MR: Bone: formation by autoinduction. Science 150: 893-899, 1965.

4. Urist MR, Iwata H, Ceccotti PL, Dorfman RL, Boyd SD, McDowell RM and Chien C: Bone morphogenesis in implants of insoluble bone gelatin. Proc Natl Acad Sci USA 70: 3511-3515, 1973.

5. Cunningham NS, Paralkar V and Reddi AH: Osteogenin and recombinant bone morphogenetic protein $2 \mathrm{~B}$ are chemotactic for human monocytes and stimulate transforming growth factor beta 1 mRNA expression. Proc Natl Acad Sci USA 89: 11740-11744, 1992.

6. Lind M, Eriksen EF and Bunger C: Bone morphogenetic protein- 2 but not bone morphogenetic protein- 4 and -6 stimulates chemotactic migration of human osteoblasts, human marrow osteoblasts, and U2-OS cells. Bone 18: 53-57, 1996.

7. Paralkar VM, Weeks BS, Yu YM, Kleinman HK and Reddi AH: Recombinant human bone morphogenetic protein $2 \mathrm{~B}$ stimulates PC12 cell differentiation: potentiation and binding to type IV collagen. J Cell Biol 119: 1721-1718, 1992.

8. Ide H, Katoh M, Sasaki H, Yoshida T, Aoki K, Nawa Y, Osada Y, Sugimura $\mathrm{T}$ and Terada M: Cloning of human bone morphogenetic protein type IB receptor (BMPR-IB) and its expression in prostate cancer in comparison with other BMPRs. Oncogene 14: 1377-1382, 1997.

9. Kim IY, Lee DH, Ahn HJ, Tokunaga H, Song W, Devereaux LM, Jin D, Sampath TK and Morton RA: Expression of bone morphogenetic protein receptors type-IA, -IB and -II correlates with tumor grade in human prostate cancer tissues. Cancer Res 60: 2840-2844, 2000.

10. Horvath LG, Henshall SM, Kench JG, Turner JJ, Golovsky D, Brenner PC, O'Neill GF, Kooner R, Stricker PD, Grygiel JJ and Sutherland RL: Loss of BMP2, Smad8, and Smad4 expression in prostate cancer progression. Prostate 59: 234-242, 2004.

11. Ide H, Yoshida T, Matsumoto N, Aoki K, Osada Y, Sugimura T and Terada M: Growth regulation of human prostate cancer cells by bone morphogenetic protein-2. Cancer Res 57: 5022-5027, 1997. 
12. Tomari K, Kumagai T, Shimizu T and Takeda K: Bone morphogenetic protein-2 induces hypophosphorylation of $\mathrm{Rb}$ protein and repression of E2F in androgen-treated LNCap human prostate canacer cells. Int J Mol Med 15: 253-258, 2005.

13. Kawabata M, Imamura T and Miyazono K: Signal transduction by bone morphogenetic proteins. Cytokine Growth Factor Rev 9: 49-61, 1998.

14. Von Bubnoff A and Cho KW: Intracellular BMP signalling regulation in vertebrates: pathway of network? Dev Biol 239: $1-14,2001$

15. De Jong DS, van Zoelen EJ, Bauerschmidt S, Olijve W and Steegenga WT: Microarray analysis of bone morphogenetic protein, transforming growth factor beta, and activin early response genes during osteoblastic cell differentiation. J Bone Miner Res 17: 2119-2129, 2002.

16. Vaes BL, Dechering KJ, Feijen A, Hendriks JM, Lefevre C, Mummery CL, Olijve W, van Zoelen EJ and Steegenga WT: Comprehensive microarray analysis of bone morphogenetic protein 2-induced osteoblast differentiation resulting in the identification of novel markers for bone development. J Bone Miner Res 17: 2106-2118, 2002.

17. Balint E, Lapointe D, Drissi H, van der Meijden C, Young DW, van Wijnen AJ, Stein JL, Stein GS and Lian JB: Phenotype discovery by gene expression profiling: mapping of biological processes linked to BMP-2-mediated osteoblast differentiation. J Cell Biochem 89: 401-426, 2003.

18. Peng Y, Kang Q, Cheng H, Li X, Sun MH, Jiang W, Luu HH, Park JY, Haydon RC and He TC: Transcriptional characterization of bone morphogenetic proteins (BMPs)-mediated osteogenic signaling. J Cell Biochem 90: 1149-1165, 2003.

19. Renault L, Nassar N, Wittinghofer A, Roth M and Vetter IR: Crystallization and preliminary X-ray analysis of human RCC1, the regulator of chromosome condensation. Acta Crystallogr D Biol Crystallogr 55: 272-275, 1999.

20. Klebe C, Prinz H, Wittinghofer A and Goody RS: The kinetic mechanism of Ran-nucleotide exchange catalyzed by RCC1. Biochemistry 34: 12543-12552, 1995.

21. Afonso A, Emmert-Buck MR, Duray PH, Bostwick DG, Linehan WM and Vocke CD: Loss of heterozygosity on chromosome 13 is associated with advanced stage prostate cancer. $\mathrm{J}$ Urol 162: 922-926, 1999.

22. Latil A, Bieche I, Pesche S, Volant A, Valeri A, Fournier G, Cussenot $\mathrm{O}$ and Lidereau R: Loss of heterozygosity at chromosome arm $13 \mathrm{q}$ and RB1 status in human prostate cancer. Hum Pathol 30: 809-815, 1999.

23. Melamed J, Einhorn JM and Ittmann MM: Allelic loss on chromosome $13 \mathrm{q}$ in human prostate carcinoma. Clin Cancer Res 3: 1867-1872, 1997.

24. Ueda T, Emi M, Suzuki H, Komiya A, Akakura K, Ichikawa T, Watanabe M, Shiraishi T, Masai M, Igarashi T and Ito $\mathrm{H}$ : Identification of a I-cM region of common deletion on 13q14 associated with human prostate cancer. Genes Chromosomes Cancer 24: 183-190, 1999.
25. Yin Z, Spitz MR, Babaian RJ, Strom SS, Troncoso P and Kagan J: Limiting the location of a putative human prostate cancer tumor suppressor gene at chromosome 13q14.3. Oncogene 18: 7576-7583, 1999.

26. Latil A, Morant P, Fournier G, Mangin P, Berthon P and Cussenot O: CHC1-L, a candidate gene for prostate carcinogenesis at $13 \mathrm{q} 14.2$, is frequently affected by loss of heterozygosity and underexpressed in human prostate cancer. Int $\mathbf{J}$ Cancer 99: 689-696, 2002.

27. Tamagnone L, Lahtinen I, Mustonen T, Virtaneva K, Francis F, Muscatelli F, Alitalo R, Smith CI, Larsson C and Alitalo K: BMX, a novel non-receptor tyrosine kinase gene of the BTK/ ITK/TEC/TXK family located in chromosome Xp22.2. Oncogene 9: 3683-3688, 1994.

28. Qiu Y, Robinson D, Pretlow TG and Kung HJ: Etk/Bmx, a tyrosine kinase with a pleckstrin-homology domain, is an effector of phosphatidylinositol 3'-kinase and is involved in interleukin 6-induced neuroendocrine differentiation of prostate cancer cells. Proc Natl Acad Sci USA 95: 3644-3649, 1998.

29. Wang W, Mariani FV, Harland RM and Luo K: Ski represses bone morphogenic protein signaling in Xenopus and mammalian cells. Proc Natl Acad Sci USA 97: 14394-14399, 2000.

30. Takeda M, Mizuide M, Oka M, Watabe T, Inoue H, Suzuki H, Fujita T, Imamura T, Miyazono K and Miyazawa K: Interaction with Smad4 is indispensable for suppression of BMP signaling by c-Ski. Mol Biol Cell 15: 963-972, 2004.

31. Wu K, Yang Y, Wang C, Davoli MA, D'Amico M, Li A, Cveklova K, Kozmik Z, Lisanti MP, Russell RG, Cvekl A and Pestell RG: DACH1 inhibits transforming growth factor-beta signaling through binding Smad4. J Biol Chem 278: 51673-51684, 2003.

32. Austin TW, Solar GP, Ziegler FC, Liem L and Matthews W: A role for the Wnt gene family in hematopoiesis: expansion of multilineage progenitor cells. Blood 89: 3624-3635, 1997.

33. Saitoh T, Mine T and Katoh M: Frequent up-regulation of WNT5A mRNA in primary gastric cancer. Int J Mol Med 9: 515-519, 2002.

34. Weeraratna AT, Jiang Y, Hostetter G, Rosenblatt K, Duray P, Bittner $\mathrm{M}$ and Trent JM: Wnt5a signaling directly affects cell motility and invasion of metastatic melanoma. Cancer Cell 1: 279-288, 2002.

35. Saitoh T and Katoh M: Expression and regulation of WNT5A and WNT5B in human cancer: up-regulation of WNT5A by TNFalpha in MKN45 cells and up-regulation of WNT5B by beta-estradiol in MCF-7 cells. Int J Mol Med 10: 345-349, 2002.

36. Iozzo RV, Eichstetter I and Danielson KG: Aberrant expression of the growth factor Wnt-5A in human malignancy. Cancer Res 55: 3495-3499, 1995. 